\title{
CAR T-CELL THERAPY OF SOLID TUMORS: PROMISING APPROACHES TO MODULATING ANTITUMOR ACTIVITY OF CAR T CELLS
}

\author{
Kiseleva YaYu $\bowtie$, Shishkin AM, Ivanov AV, Kulinich TM, Bozhenko VK
}

Russian Scientific Center of Roentgenoradiology, Moscow, Russia

\begin{abstract}
Adoptive immunotherapy that makes use of genetically modified autologous T cells carrying a chimeric antigen receptor (CAR) with desired specificity is a promising approach to the treatment of advanced or relapsed solid tumors. However, there are a number of challenges facing the CAR T-cell therapy, including the ability of the tumor to silence the expression of target antigens in response to the selective pressure exerted by therapy and the dampening of the functional activity of CAR T cells by the immunosuppressive tumor microenvironment. This review discusses the existing gene-engineering approaches to the modification of CAR T-cell design for 1) creating universal "switchable" synthetic receptors capable of attacking a variety of target antigens; 2) enhancing the functional activity of CART cells in the immunosuppressive microenvironment of the tumor by silencing the expression of inhibiting receptors or by stimulating production of cytokines.
\end{abstract}

Keywords: CAR T-cell therapy, solid tumors, chimeric antigen receptor, CAR T cells, universal CARs, immunosuppressive microenvironment

Author contribution: Kiseleva YaYu analyzed the literature, prepared the draft of the manuscript, created the figures; Shishkin AM analyzed the literature and revised the manuscript; Ivanov AV analyzed the literature and revised the manuscript; Kulinich TM revised the manuscript; Bozhenko VK revised the manuscript.

Correspondence should be addressed: Yana Yu. Kiseleva

Profsoyuznaya, 86, Moscow, 117997; 89036728541 yana.kiseleva@gmail.com

Received: 03.10.2019 Accepted: 17.10.2019 Published online: 18.10.2019

DOI: $10.24075 /$ brsmu.2019.066

\section{CAR-TЕРАПИЯ СОЛИДНЫХ ОПУХОЛЕЙ: ПЕРСПЕКТИВНЫЕ ПОДХОДЫ К МОДУЛИРОВАНИЮ ПРОТИВООПУХОЛЕВОЙ АКТИВНОСТИ САR-Т-ЛИМФОЦИТОВ}

\author{
Я. Ю. Киселева $\bowtie$, А. М. Шишкин, А. В. Иванов, Т. М. Кулинич, В. К. Боженко
}

Российский научный центр рентгенорадиологии, Москва, Россия

\begin{abstract}
Адоптивную иммунотерапию, использующую генно-модифицированные аутологичные Т-лимфоциты с искусственным рецептором заданной специфичности (CAR-терапию) рассматривают в качестве перспективного подхода к лечению солидных опухолей, как рецидивирующих, так и на поздних стадиях развития. При использовании этого вида терапии приходится сталкиваться с рядом проблем, таких как способность опухоли к отбору клеток со сниженной экспрессией антигенов-мишеней в ходе терапии и снижение функциональной активности CAR-T-лимфоцитов иммуносупрессивным микроокружением опухоли. В обзоре обсуждены существующие генно-инженерные подходы к модификации технологии получения CAR-T-лимфоцитов для: 1) создания универсальных искусственных рецепторов, способных в ходе иммунотерапии переключаться и атаковать различные антигены-мишени; 2) повышения функциональной активности CAR-T-лимфоцитов в условиях иммуносупрессивного микроокружения путем подавления экспрессии ингибирующих рецепторов или повышения продукции цитокинов.
\end{abstract}

Ключевые слова: CAR-терапия, солидные опухоли, химерный антигенный рецептор, CAR-Т-клетки, универсальные CAR, иммуносупрессивное микроокружение Информация о вкладе авторов: Я. Ю. Киселева - анализ литературы, написание рукописи, подготовка рисунков, редактирование; А. М. Шишкин и А. В. Иванов - анализ литературы, редактирование; Т. М. Кулинич и В. К. Боженко - редактирование.

$\triangle$ Для корреспонденции: Яна Юрьевна Киселева

ул. Профсоюзная, д. 86, г. Москва, 117997; yana.kiseleva@gmail.com

Статья получена: 03.10.2019 Статья принята к печати: 17.10.2019 Опубликована онлайн: 18.10.2019

DOI: 10.24075/vrgmu.2019.066

Traditional treatment options for malignancies, such as surgery, radiation therapy and chemotherapy, do not satisfy the criteria for therapeutic efficacy in patients with advanced or relapsed cancer. The need for more effective therapies has driven development of innovative treatment modalities, many of which harness the mechanisms of immune response [1]. One of them is adoptive immunotherapy that makes use of T-cell chimeric antigen receptors (CARs). Eligible patients receive an infusion of autologous $T$ cells genetically modified ex vivo before the procedure to carry a synthetic receptor with a desired specificity on their surface. A CAR is a fusion protein composed of an extracellular single-chain variable immunoglobulin fragment (scFv) and T-cell intracellular signaling domains [2]. Unlike T-cell receptors that recognize antigens processed and embedded within the major histocompatibility complex, chimeric T-cell receptors target native (unprocessed) cell surface antigens associated with malignant cell transformation [3]. Despite the success of CAR T-cell therapy in fighting hematologic malignancies [4], its application to solid tumors has a few limitations related to the presence of tumor-associated antigens on the surface of healthy tissue cells and the ensuing adverse cytotoxicity $[5,6]$. Another challenge is that malignant tumors are heterogenous and can evolve under selective pressure induced by immunotherapy, expressing fewer target antigens on their surface. In addition, once a CAR $T$ cell reaches the tumor, it finds itself in the immunosuppressive microenvironment created by regulatory $T$ cells, tumor-associated macrophages, myeloid-derived suppressor cells, some overexpressed immunosuppressive molecules (PD-L1, PD-L2, CD80, CD86), hypoxia, necrosis, and lack of nutrients [7].

In order to overcome these barriers, a variety of gene engineering approaches have been proposed to the modification of CAR T-cell manufacturing technology [7-9]. The most promising of them include 1) designing universal CARs capable of attacking a wide range of target antigens and 2) enhancing functional activity of CAR T cells in the immunosuppressive microenvironment of the tumor. This review focuses on genetically engineered universal CARs and the possibility of modulating antitumor activity of CAR T cells by downregulating the expression of inhibiting receptors and stimulating production of cytokines. 


\section{Universal CARs with an adaptor module}

Since classic, i.e. currently used in clinical practice, CARs are monospecific, antigen loss provoked by therapy remains one of the crucial challenges facing CAR therapy. In order to cut down on manufacturing costs and effort involved in creating a CAR construct with new (yet fixed) specificity, as well as to expand the range of simultaneously or consecutively attacked targets, a modular design of the CAR T-cell system has been proposed in which the antigen-recognition and signaling domains are represented by two separate modules. The antigen-binding adaptor is a stand-alone molecule recognized by a CAR ectodomain. Such system can be functional only in the presence of all 3 components, including the target, the adaptor module and the effector CAR T cell. Its design allows controlled activation of CAR T cells and their rapid "switch-off" in case of toxic adverse events, such as the cytokine release syndrome. In addition, a modular CAR T cell can be easily redirected from one target to another, without having to start the engineering process all over in an attempt to obtain a cell with new antigen specificity. This concept lies behind the idea of a universal CAR system (UniCAR). This review looks at the most promising universal CAR systems developed so far.

\section{A modular CAR system equipped with biotin-binding immunoreceptors}

In this type of UniCAR T cells, the universal ectodomain is represented by avidin or streptavidin (Fig. 1A) that bind to biotinylated antigen-specific molecules (MAT, ScFv and other specific ligands that recognize the target antigen). The first UniCAR system exploited the interaction between biotin and avidin [10]. Its inventors demonstrated that $T$ cells equipped with the biotin-binding immunoreceptor (BBIR), whose ectodomain was represented by an extracellularly modified avidin dimer, could bind to cancer cells pre-incubated with biotinylated antibodies, switch on and lyse the malignant target. The researchers showed that supraphysiological concentrations of biotin, which is present in human blood plasma, did not cause antigen-independent activation of modified CAR T cells and did not inhibit their activity. Biotinylated antibodies were also employed as adaptor modules in another UniCAR system described in [11]. Here, the role of the ectodomain component was played by a high-affinity streptavidin monomer (mSA2). Using biotinylated rituximab (anti-CD20 mAb) as an adaptor module, the researchers demonstrated that modified $T$ cells were capable of switching on and lysing their targets in a dosedependent manner in vitro. However, the immunogenicity of avidin/streptavidin remains an open question and can limit therapeutic applications of BBIR-based UniCAR T-cell systems $[10,11]$

\section{A modular CAR-system containing fluorescein isothiocyanate}

In this modular system (Fig. 1B), the universal CAR T-cell ectodomain contains a variable scFv fragment that targets synthetic fluorescein isothiocyanate (FITC), a commonly used fluorescent probe for antibody labeling. Here, FITC is conjugated either to a monoclonal antibody (mAb) or to a receptor ligand that interacts with a target antigen on the surface of the malignant cell. This interaction results in a pseudoimmunological synapse formed between the anti-FITC CAR T cell and the tumor cell expressing the target antigen. Subsequently, the activated CAR T cells lyse the target. CAR T-cell constructs carrying FITC conjugated to $\mathrm{mAb}$ (trastuzumab, rituximab and cetuximab) were successfully tested against HER2-expressing cells (breast cancer), CD20 (B-cell lymphoma) and EGFR (pancreatic cancer) in NSG mice [12]. Just like BBIR-based UniCAR T cells, the immunogenicity of FITS is yet to be elucidated [12].

\section{Modular CAR systems with neoepitopes}

In this type of CAR systems, the adaptor module contains a neoepitope bound to antigen-specific scFv or Fab, whereas the CAR itself consists of an intracellular domain and an ectodomain (scFv) that recognizes the neoepitope. Neoepitopes are exogenous peptides not found in humans. So far, two modular neoepitope CAR T-cell systems have been developed; they rely on neoepitopes 5B9 and PNE (Fig. 1C).

5B9 is a non-immunogenic peptide 10 amino acids in length. Its sequence is a peptide motif present in the nuclear autoantigen La/SS-B typically found in patients with Sjögren's syndrome and systemic lupus erythematosus [13]. Initially, the developed 5B9-specific UniCAR system [14] was directed against antigens CD33 and CD123 expressed on acute myeloid leukemia cells. The researchers experimented with both mono- and bispecific antigen-recognizing modules conjugated to epitope 5B9. The targeted cells were effectively lysed both in the presence of two independent monomodules (scFv) and the bispecific module (bis-scFv) alone; the latter turned out to be even more effective. It was established that antigen-recognizing modules could effectively induce lysis

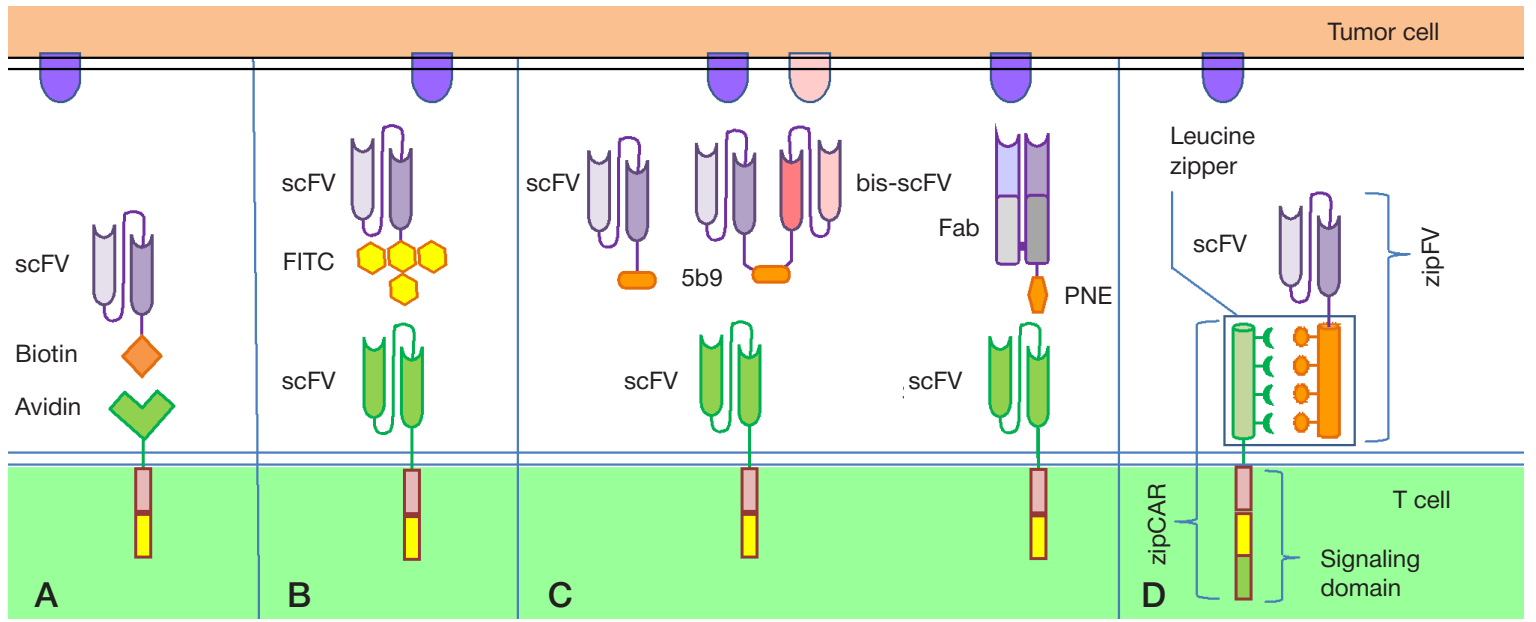

Fig. 1. Types of universal CARs. A. A modular CAR T-cell system with biotin-binding immunoreceptors. B. A modular CAR T-cell system with fluorescein isothiocyanate. C. A modular CAR T-cell system with neoepitopes (5B9, PNE). D. A modular CAR T-cell system with a leucine zipper motif (SUPRA CAR) 
even at very low concentrations, regardless of antigen density on the surface of targeted cells [14]. Later, the efficacy of the 5B9-specific UniCAR-system against solid tumors was tested in cell and animal models of prostate cancer [15]. In this case, the neoepitope 5B9 was bound to scFv directed against prostate stem cell antigen (PSCA). The use of the 5B9-specific UniCAR system in NSG mice with high and low tumor burden significantly delayed tumor growth and improved animal survival. Interestingly, after the adaptor module was added to the co-cultured cancer and 5B9-specific UniCAR T cells, the expression of immunosuppressing PD-L1 and PD-L2 on the cancer cells and their PD-1 receptor on effector $T$ cells significantly increased in comparison with the control cultured without the adaptor module [15]. Later, the same research team [16] published preclinical trial data on the successful application of PSCA- and PSMA-specific (prostate specific membrane antigen) 5B9-modules used in combination.

The other peptide known as PNE (peptide neoepitope) and exploited in a neoepitope UniCAR (Fig. 1C) was derived from GCN4, the transcription factor found in yeast. PNE contains 14 amino acid residues, is not found in humans and is expected to have low immunogenicity, according to the in silico analysis. Proposed in [17], the PNE-based adaptor module contained a PNE bound to a Fab fragment of therapeutic antibodies specific either for CD19 or for CD20. The universal CAR ectodomain contained scFv of highly specific 52SR4 mAb that recognize PNE. Using the mouse model of B-cell leukemia xenograft, the researchers demonstrated dose-dependent control over the activity of UniCAR T cells and their localization in tissue in the areas of malignant cell accumulation and cytokine secretion [17]. Interestingly, high doses of adaptor modules caused expansion of CD45RA ${ }^{+} \mathrm{CD} 62 \mathrm{~L}^{-}$cells (TEMRA, terminal effector memory expressing CD45RA+), whereas low adaptor doses led to the prevalence of the CD45RA-CD62 $\mathrm{L}^{+}$phenotype (central memory cells) associated with prolonged persistence of CAR $T$ cells and correlated with sustained remission in patients with acute myeloid leukemia or chronic lymphocyte leukemia [18]. The same research team developed a UniCAR-system with PNE targeting the HER2-expressing breast cancer cells [19]. The antigen-recognizing component of the adaptor module was represented by the Fab fragment of trastuzumab (clone 4D5). The study [19] demonstrated a dose-dependent cytotoxic effect exerted by the system in vitro, as well as complete resolution of lesions in NSG mice inoculated subcutaneously with breast cancer cell lines characterized by different levels of HER2 expression.

\section{SUPRA CAR: a modular CAR-system with a leucine zipper motif component}

One of the most promising universal CARs is known as SUPRA CAR (split, universal and programmable) and was proposed in [20] (Fig. 1D). It is a two-component system that relies on a leucine zipper motif to ensure the interaction between its parts. The zipper is composed of a universal receptor (zipCAR) expressed on the T-cell surface and an antitumor ScFv adaptor (zipFv). The universal zipCAR receptor rises from the fusion of intracellular signaling domains (CD28, 4-1BB and CD3z) with the ectodomain containing a leucine zipper motif. The adaptor module zipFv consists of an antigen-specific scFv and a leucine zipper motif, which ensures its interaction with zipCAR and subsequent activation of T cells. Unlike "conventional" CARs with fixed specificity, the described construct allows redirecting the system against different antigen targets without preforming any extra manipulations on a patient's immune cells. Another unique feature of SUPRA CAR is its tunability: it is possible to adjust the wide range of different parameters involved in modulating T-cell response and prevent T-cell overactivation. By varying such parameters as (1) affinity between leucine zipper motifs, (2) affinity between the tumor antigen and scFv, (3) zipFv concentrations, and (4) zipCAR expression, one can modulate the functional activity of $T$ cells, including interferon gamma production [20]. In case of a cytokine storm occurring in response to CAR therapy, the activity of SUPRA CAR T cells can be dampened or completely inhibited by administering a competing low/high-affinity adaptor zipFv to the patient. The adaptor can dimerize with the leucine zipper domain of specific zipFv introduced into the patient's organism in the previous step, and thus prevent it from binding to zipCAR. Besides, this system can perform such logic operations as A OR B or A AND NOT $B$. The former is used when there is a need to attack malignant cells carrying two target antigens, which is achieved by adding two zipFv adaptors specific for the two targets and capable of binding to zipCAR. The second logic operation is performed to mitigate adverse cytotoxic effects on healthy cells expressing the target antigen. The researchers demonstrated

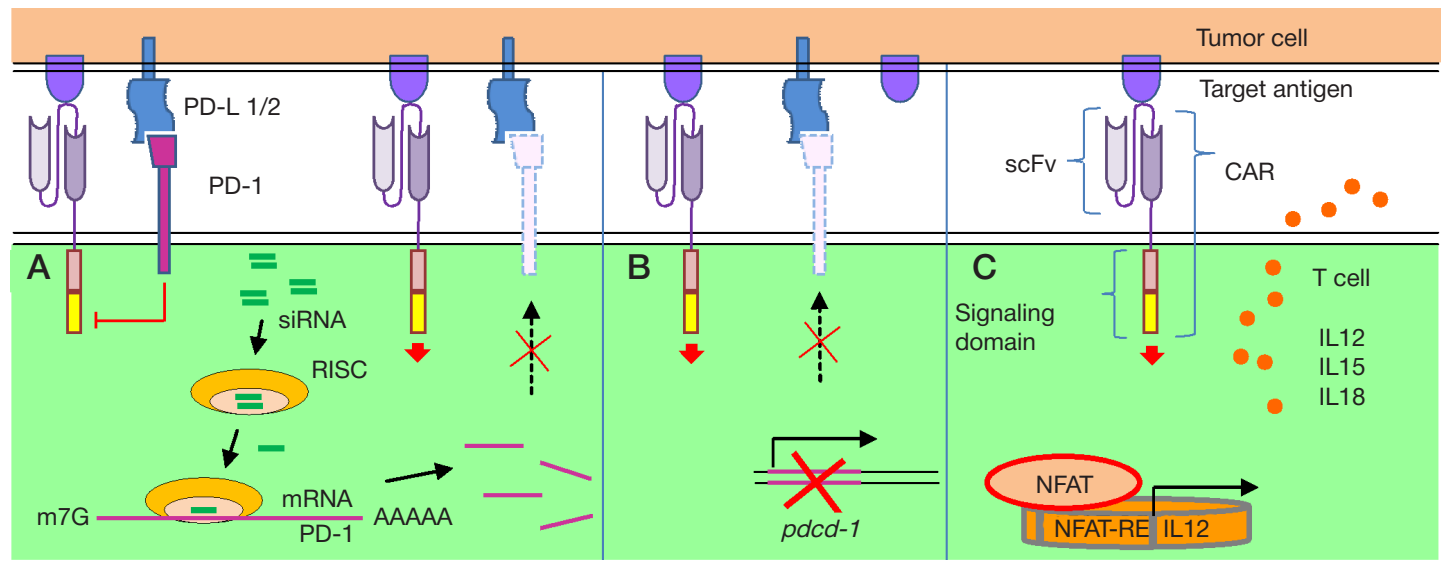

Fig. 2. A schematic showing modulation of antitumor activity of CAR T cells in the immunosuppressive tumor microenvironment. A. Silencing the expression of the pdcd-1 gene in T lymphocytes by transfecting them with siRNA. The PD-1 receptor interacts with its ligands PD-L1/2 and inhibits the activating CAR signal. After transfection, siRNA duplexes interact with the RISC-binding complex (RNA-induced silencing complex); one of RNA strands is removed from the complex, whereas the other remains within RISC, binds to mRNA and initiates its degradation. This leads to a decline in the PD-1 expression on the cell surface. B. Knockout of the pdcd-1 gene performed using CRISPR/Cas9 technology. C. TRUCKs: apart from CAR, a plasmid is introduced into the T cell, containing a NFAT responsive element (NFAT-RE) and sequences of genes coding for IL12, IL15 or IL18. The T cell is activated following the interaction between the CAR and the target antigen. This leads to dephosphorylation of NFAT transcription factor that relocates to the nucleus and triggers cytokine production by binding to NFAR-RE. Local secretion of the cytokine initiates immune response against cancer cells invisible for CAR T lymphocytes 
the feasibility of sparing cells that carry 2 target antigens, one of which was tumor-associated and the other was non-tumor [20]. This effect can be achieved by using the zipFv adaptor that is specific for a non-tumor antigen but competes with zipCAR for binding to the leucine zipper domain of the zipFv adaptor specific for the tumor antigen. When bound to the target, the adaptors form dimers, meaning that zipFv specific for the tumor antigen can no longer interact with zipCAR. As a result, the induced cytotoxic response of $T$ cells against healthy cells is weak. It was demonstrated that SUPRA CAR $T$ cells can control tumor growth in NSG mice injected with SK-BR-3 breast cancer cells intraperitoneally or with Jurkat cells intravenously [20]. In order to reduce immunogenicity of the proposed system, the authors humanized leucine zippers using the corresponding sequences of human transcription factors [20].

\section{Modulation of antitumor activity of CAR T cells in the immunosuppressive tumor microenvironment}

The immunosuppressive microenvironment of solid tumors is one of the major factors preventing the positive outcome of CAR therapy. Coupled with the expression of inhibiting receptors on the surface of CAR T cells, it disrupts the efficacy of the latter [21]. The following 2 inhibiting receptors are worth noting: PD-1 (programmed cell death receptor) and CTLA-4 (cytotoxic T-cell-associated antigen 4); today, they are regarded as leading regulators of the immune system that control the activation of $T$ cells and maintain peripheral tolerance $[7,22]$. By interacting with CD80/86, CTLA-4 inhibits potentially autoreactive $T$ cells in the early stage of naive T-cell activation, usually in lymph nodes [23], whereas PD1 bound to PD-L1/2 participates in the regulation of activated cells in later stages of immune response, exerting its effect in peripheral tissue [24]. Tumor cells expressing the corresponding ligands on their surface can harness those two receptors to inactivate tumorspecific lymphocytes, including CAR $T$ cells, thus acquiring insensitivity to their attacks [22, 25]. Importantly, adoptive immunotherapy makes use of activated $T$ cells. Their activation leads to overexpression of PD-1 and CTLA-4, which makes $T$ cells even more susceptible to the immunosuppressive effect of the tumor [25].

The unwanted interaction between the ligand and the receptor can be blocked by mAb specific for this receptor or ligand [26]. Since 2011, therapeutic regimens for metastatic melanoma adopted in the USA have included ipilimumab, the monoclonal antibody that blocks CTLA-4 [27]. Clinical trials have demonstrated the efficacy of immunotherapy with PD-1 and PD-L1 inhibitors in patients with melanoma [28]. It should be noted that the combination therapy with anti-PD-1 (nivolumab) and anti-CTLA-4 (ipilimumab) improved progression-free survival and increased the objective response rate in patients with melanoma who had not received any previous treatment, as compared with monotherapy [29]. Today, a number of antimAb have been approved for treating melanoma, non-small cell lung cancer, bladder cancer, and some other types of cancers, including nivolumab, pembrolizumab, atezolizumab, avelumab, and durvalumab [27]. However, these drugs induce a wide range of side effects called immune-related adverse events, including autoimmune thyroiditis, hepatitis, colitis, myocarditis, etc. [30]. Apparently, immunomediated adverse effects are related to non-specific activation of immunocompetent cells, limiting the therapeutic application of such drugs [30].

An alternative approach to the modification of functional activity of CAR T cells is based on silencing the expression of inhibiting receptors on their surface through genetic modification of $T$ cells ex vivo in addition to the introduction of an antigen-specific CAR receptor into the cell. This can be done by simultaneously transfecting the T cell with siRNA (small interfering RNA) (Fig. 2A) and DNA/RNA coding for the antigenspecific receptor [22], or by using genome editing tools, such as CRISPR/Cas9 [31] (Fig. 2B). A study [32] has demonstrated that CTLA-4 mRNA expression can be successfully silenced in the peripheral blood lymphocytes of patients with chronic hepatitis B using the siRNA-based technology. It should be noted though that in the mentioned experiment specific CAR receptors were not introduced into the cells. Another recent study has shown that transfection of T-cells with mRNA coding for the second-generation CAR-receptor specific for the melanoma antigen CSPG4 and two siRNAs inhibiting PD-1 and CTLA-4 leads to a decline in the expression of surface PD-1 and intracellular CTLA-4 in T lymphocytes [25]. The researchers observed a statistically significant increase in the cytotoxic effect of modified T lymphocytes on melanoma cells transfected with PD-L1- or CD80-encoding plasmids, in comparison with the control [25]. CRISPR/Cas9-based genome editing has been recently applied to suppress the expression of PD-1 and CTLA4 [31, 33]. The CRISPR/Cas9 technology can be successfully used to silence the PD-1-encoding gene in CAR T cells; this significantly enhances their antitumor activity both in vitro and in vivo [33]. It has been shown that three genes, including PD-1 [31], and 4 genes, including PD-1 and CTLA-4 [34], can be simultaneously silenced in CAR T cells using the CRISPR/Cas9 technology.

Another approach to overcoming the immunosuppressive activity of tumor environment and attacking tumor cells that have stopped expressing the target antigen on their surface lies in enabling $T$ cells to increase production of cytokines directly in target tissue upon their activation through the interaction between CAR and the target cell. Such modified cytokineproducing CAR $T$ cells are referred to as TRUCKs: T cells Redirected for Universal Cytokine Killing [35] (Fig. 2C). They have proved to be highly effective in delivering cytokines to the tumor microenvironment. Experiments in mouse models have demonstrated that accumulation of IL12 in malignant tissue following adoptive transfer of tumor-specific IL12-secreting cells improves the cytolytic activity of $\mathrm{T}$ lymphocytes [36] and stimulates activation and recruitment of innate immunity cells to the tumor site [37]. Secretion of IL12 locally affects myeloid suppressor cells, dysfunctional dendritic cells and alternatively activated macrophages and reprograms them into functional antigen-presenting cells that can present tumor-associated antigens to tumor-infiltrating lymphocytes (TIL), causing regression of large tumor lesions [38]. Clinical trials conducted in patients with metastatic melanoma treated with autologous TIL expressing IL12 under the "supervision" of regulatory NFAT (NFAT stands for nuclear factor of activated T cells) have demonstrated an objective clinical effect in 10 out of 16 patients treated with lower cell doses than recommended in the standard protocol [39]. However, many patients recruited for the trial developed serious side effects, such as severe hepatotoxicity and hemodynamic instability; therefore, the trial was terminated [39]. Pronounced cytotoxicity of TCR T cells with NFAT-regulated expression of IL12 has been detected in vivo in the experiments in mice [40]. Another research group has achieved a positive therapeutic outcome (the absence of toxicity in vivo) by controlling the IL12 expression with the TET-On promotor sensitive to doxycycline [45]. Transient expression of IL12 was enough to inhibit the growth of B16F10 melanoma without provoking systemic cytotoxicity. 
There have been studies investigating the effect of the increased IL15 and IL18 expression on the antitumor activity of CAR T cells and TCR T cells. It has been established that IL15 improves survival and promotes proliferation of ex vivo modified CAR T cells redirected against CD19 (in leukemia/ lymphoma) [42] and IL13R $\alpha 2$ (in glioblastoma) [43]. Using the melanoma mouse model, the researchers have demonstrated that administration of modified TCR $\mathrm{T}$ cells with NFATregulated expression of IL18 was safe (no adverse toxicity was observed), resulted in the expansion of CD8-cells in the lesion and increased antitumor activity [40]. CD4 CAR T cells secreting IL18 have been shown to activate CD8 T-cells that, in turn, proliferate and enhance the antitumor response in mice with induced B16F10 melanoma [44]. CAR T cells secreting IL18 trigger acute Th1 immune response in the tumor, which results in improved survival of mice with pancreatic and lung cancer [45].

\section{CONCLUSION}

At present, CAR T-cell therapy is successfully used in clinical practice in patients with hematologic malignancies. However, this positive experience cannot be extrapolated to solid tumors because of the adverse events associated with CAR T-cell toxicity against healthy cells and the inhibiting effect of the immunosuppressive tumor microenvironment on the functional activity of CAR T cells. A few solutions have been proposed, including universal CARs that can be quickly redirected against a new antigen target and CAR T cells that have been genetically modified to resist the immunosuppressive effect of the tumor microenvironment. Results of extensive research in this field instill hope for creating an arsenal of effective and therapeutically safe CAR T cells that can be used to treat solid tumors.

\section{References}

1. Palucka AK, Coussens LM. The Basis of Oncoimmunology. Cell. 2016; 164 (6): 1233-47. DOI: 10.1016/j.cell.2016.01.049. PubMed PMID: 26967289; PubMed Central PMCID: PMC4788788.

2. Jena B, Dotti G, Cooper LJ. Redirecting T-cell specificity by introducing a tumor-specific chimeric antigen receptor. Blood. 2010; 116 (7): 1035-44. DOI: 10.1182/blood-2010-01-043737. PubMed PMID: 20439624; PubMed Central PMCID: PMC2938125.

3. Klebanoff CA, Rosenberg SA, Restifo NP. Prospects for geneengineered $T$ cell immunotherapy for solid cancers. Nature medicine. 2016; 22 (1): 26-36. DOl: 10.1038/nm.4015. PubMed PMID: 26735408; PubMed Central PMCID: PMC6295670,

4. Park JH, Geyer MB, Brentjens RJ. CD19-targeted CAR T-cell therapeutics for hematologic malignancies: interpreting clinical outcomes to date. Blood. 2016; 127 (26): 3312-20. DOl: 10.1182/blood-2016-02-629063. PubMed PMID: 27207800 PubMed Central PMCID: PMC4929923.

5. Liu B, Yan L, Zhou M. Target selection of CAR T cell therapy in accordance with the TME for solid tumors. American journal of cancer research. 2019; 9 (2): 228-41. PubMed PMID: 30906625; PubMed Central PMCID: PMC6405971.

6. Bonifant $\mathrm{CL}$, Jackson HJ, Brentjens RJ, Curran KJ. Toxicity and management in CAR T-cell therapy. Molecular therapy oncolytics. 2016; (3): 16011. DOI: 10.1038/mto.2016.11. PubMed PMID: 27626062; PubMed Central PMCID: PMC5008265.

7. Tahmasebi S, Elahi R, Esmaeilzadeh A. Solid Tumors Challenges and New Insights of CAR T Cell Engineering. Stem cell reviews and reports. 2019; 15 (5): 619-36. DOI: 10.1007/s12015-01909901-7. PubMed PMID: 31161552.

8. Minutolo NG, Hollander EE, Powell DJ, Jr. The Emergence of Universal Immune Receptor T Cell Therapy for Cancer. Frontiers in oncology. 2019; (9): 176. DOI: 10.3389/fonc.2019.00176. PubMed PMID: 30984613; PubMed Central PMCID: PMC6448045.

9. Stoiber S, Cadilha BL, Benmebarek MR, Lesch S, Endres S, Kobold S. Limitations in the Design of Chimeric Antigen Receptors for Cancer Therapy. Cells. 2019; 8 (5). DOI: 10.3390/cells8050472. PubMed PMID: 31108883; PubMed Central PMCID: PMC6562702.

10. Urbanska K, Lanitis E, Poussin M, Lynn RC, Gavin BP, Kelderman S, et al. A universal strategy for adoptive immunotherapy of cancer through use of a novel T-cell antigen receptor. Cancer research. 2012; 72 (7): 1844-52. DOI: 10.1158/0008-5472.CAN-11-3890. PubMed PMID: 22315351; PubMed Central PMCID: PMC3319867.

11. Lohmueller JJ, Ham JD, Kvorjak M, Finn OJ. mSA2 affinityenhanced biotin-binding CAR $T$ cells for universal tumor targeting. Oncoimmunology. 2017; 7 (1): e1368604. DOl: 10.1080/2162402X.2017.1368604. PubMed PMID: 29296519; PubMed Central PMCID: PMC5739565.
12. Tamada K, Geng D, Sakoda Y, Bansal N, Srivastava R, Li Z, et al. Redirecting gene-modified $T$ cells toward various cancer types using tagged antibodies. Clinical cancer research: an official journal of the American Association for Cancer Research. 2012; 18 (23): 6436-45. DOI: 10.1158/1078-0432.CCR-12-1449. PubMed PMID: 23032741

13. Koristka S, Cartellieri M, Arndt C, Bippes CC, Feldmann A, Michalk I, et al. Retargeting of regulatory $T$ cells to surfaceinducible autoantigen La/SS-B. Journal of autoimmunity. 2013; (42): 105-16. DOI: 10.1016/j.jaut.2013.01.002. PubMed PMID: 23352111

14. Cartellieri M, Feldmann A, Koristka S, Arndt C, Loff S, Ehninger A, et al. Switching CAR T cells on and off: a novel modular platform for retargeting of T cells to AML blasts. Blood cancer journal. 2016; 6 (8): e458. DOI: 10.1038/bcj.2016.61. PubMed PMID: 27518241; PubMed Central PMCID: PMC5022178 directed to CD33, La and the UniCAR platform technology. AE, SL and MC are employed by GEMoaB and CPT, respectively. The other authors declare no conflict of interest.

15. Pishali Bejestani E, Cartellieri M, Bergmann R, Ehninger A, Loff S, Kramer $\mathrm{M}$, et al. Characterization of a switchable chimeric antigen receptor platform in a pre-clinical solid tumor model. Oncoimmunology. 2017; 6 (10): e1342909. DOI: 10.1080/2162402X.2017.1342909. PubMed PMID: 29123951; PubMed Central PMCID: PMC5665068.

16. Feldmann A, Arndt C, Bergmann R, Loff S, Cartellieri M, Bachmann D, et al. Retargeting of T lymphocytes to PSCA- or PSMA positive prostate cancer cells using the novel modular chimeric antigen receptor platform technology "UniCAR". Oncotarget. 2017; 8 (19): 31368-85. DOI: 10.18632/oncotarget.15572. PubMed PMID: 28404896; PubMed Central PMCID: PMC5458214.

17. Rodgers DT, Mazagova M, Hampton EN, Cao Y, Ramadoss NS, Hardy IR, et al. Switch-mediated activation and retargeting of CAR-T cells for B-cell malignancies. Proceedings of the National Academy of Sciences of the United States of America. 2016; 113 (4): E459-68. DOI: 10.1073/pnas.1524155113. PubMed PMID: 26759369; PubMed Central PMCID: PMC4743815.

18. Riddell SR, Sommermeyer D, Berger C, Liu LS, Balakrishnan A, Salter A, et al. Adoptive therapy with chimeric antigen receptormodified T cells of defined subset composition. Cancer journal. 2014; 20 (2): 141-4. DOl: 10.1097/PPO.0000000000000036. PubMed PMID: 24667960; PubMed Central PMCID: PMC4149222.

19. Cao Y, Rodgers DT, Du J, Ahmad I, Hampton EN, Ma JS, et al. Design of Switchable Chimeric Antigen Receptor T Cells Targeting Breast Cancer. Angewandte Chemie. 2016; 55 (26): 7520-4. DOI: 10.1002/anie.201601902. PubMed PMID: 27145250; PubMed Central PMCID: PMC5207029.

20. Cho JH, Collins JJ, Wong WW. Universal Chimeric Antigen Receptors for Multiplexed and Logical Control of $T$ Cell Responses. Cell. 2018; 173 (6): 1426-38. DOI: 10.1016/j. 
cell.2018.03.038. PubMed PMID: 29706540; PubMed Central PMCID: PMC5984158.

21. Scarfo I, Maus MV. Current approaches to increase CAR T cell potency in solid tumors: targeting the tumor microenvironment. Journal for immunotherapy of cancer. 2017; (5): 28. DOI: 10.1186/ s40425-017-0230-9. PubMed PMID: 28331617; PubMed Central PMCID: PMC5359946.

22. Sioud M. Releasing the Immune System Brakes Using siRNAs Enhances Cancer Immunotherapy. Cancers. 2019; 11 (2). DOI: 10.3390/cancers11020176. PubMed PMID: 30717461.

23. Boutros C, Tarhini A, Routier E, Lambotte O, Ladurie FL, Carbonnel F, et al. Safety profiles of anti-CTLA-4 and anti-PD-1 antibodies alone and in combination. Nature reviews Clinical oncology. 2016; 13 (8): 473-86. DOI: 10.1038/nrclinonc.2016.58. PubMed PMID: 27141885.

24. Hugo W, Zaretsky JM, Sun L, Song C, Moreno BH, Hu-Lieskovan S, et al. Genomic and Transcriptomic Features of Response to AntiPD-1 Therapy in Metastatic Melanoma. Cell. 2016; 165 (1): 3544. DOI: 10.1016/j.cell.2016.02.065. PubMed PMID: 26997480 PubMed Central PMCID: PMC4808437.

25. Simon B, Harrer DC, Schuler-Thurner B, Schaft N, Schuler G, Dorrie J, et al. The siRNA-mediated downregulation of PD-1 alone or simultaneously with CTLA-4 shows enhanced in vitro CAR-T-cell functionality for further clinical development towards the potential use in immunotherapy of melanoma. Experimental dermatology. 2018; 27 (7): 769-78. DOI: 10.1111/exd.13678. PubMed PMID: 29704887

26. Martinez M, Moon EK. CAR T Cells for Solid Tumors: New Strategies for Finding, Infiltrating, and Surviving in the Tumor Microenvironment. Frontiers in immunology. 2019; (10): 128. DOI: 10.3389/fimmu.2019.00128. PubMed PMID: 30804938; PubMed Central PMCID: PMC6370640.

27. Vivot A, Jacot J, Zeitoun JD, Ravaud P, Crequit P, Porcher R Clinical benefit, price and approval characteristics of FDAapproved new drugs for treating advanced solid cancer, 20002015. Annals of oncology: official journal of the European Society for Medical Oncology. 2017; 28 (5): 1111-6. DOI: 10.1093/ annonc/mdx053. PubMed PMID: 28453694.

28. Medina PJ, Adams VR. PD-1 Pathway Inhibitors: ImmunoOncology Agents for Restoring Antitumor Immune Responses. Pharmacotherapy. 2016; 36 (3): 317-34. DOI: 10.1002/phar.1714. PubMed PMID: 26822752; PubMed Central PMCID: PMC5071694.

29. Larkin J, Chiarion-Sileni V, Gonzalez R, Grob JJ, Cowey CL, Lao CD, et al. Combined Nivolumab and Ipilimumab or Monotherapy in Untreated Melanoma. The New England journal of medicine. 2015; 373 (1): 23-34. DOI: 10.1056/NEJMoa1504030. PubMed PMID: 26027431; PubMed Central PMCID: PMC5698905.

30. Postow MA, Sidlow R, Hellmann MD. Immune-Related Adverse Events Associated with Immune Checkpoint Blockade. The New England journal of medicine. 2018; 378 (2): 158-68. DOI: 10.1056/NEJMra1703481. PubMed PMID: 29320654.

31. Ren J, Liu X, Fang C, Jiang S, June $\mathrm{CH}$, Zhao Y. Multiplex Genome Editing to Generate Universal CAR T Cells Resistant to PD1 Inhibition. Clinical cancer research: an official journal of the American Association for Cancer Research. 2017; 23 (9): 225566. DOI: 10.1158/1078-0432.CCR-16-1300. PubMed PMID: 27815355; PubMed Central PMCID: PMC5413401.

32. Yu Y, Wu H, Tang Z, Zang G. CTLA4 silencing with siRNA promotes deviation of Th1/Th2 in chronic hepatitis B patients. Cellular \& molecular immunology. 2009; 6 (2): 123-7. DOI: 10.1038/cmi.2009.17. PubMed PMID: 19403062; PubMed Central PMCID: PMC4002649.

33. Rupp LJ, Schumann K, Roybal KT, Gate RE, Ye CJ, Lim WA, et al. CRISPR/Cas9-mediated PD-1 disruption enhances antitumor efficacy of human chimeric antigen receptor $\mathrm{T}$ cells. Scientific reports. 2017; 7 (1): 737. DOI: 10.1038/s41598-01700462-8. PubMed PMID: 28389661; PubMed Central PMCID: PMC5428439.
34. Ren J, Zhang X, Liu X, Fang C, Jiang S, June $\mathrm{CH}$, et al. A versatile system for rapid multiplex genome-edited CAR T cell generation. Oncotarget. 2017; 8 (10): 17002-11. DOI: 10.18632/ oncotarget.15218. PubMed PMID: 28199983; PubMed Central PMCID: PMC5370017.

35. Knochelmann HM, Smith AS, Dwyer CJ, Wyatt MM, Mehrotra S, Paulos CM. CAR T Cells in Solid Tumors: Blueprints for Building Effective Therapies. Frontiers in immunology. 2018; (9): 1740. DOI: 10.3389/fimmu.2018.01740. PubMed PMID: 30140266; PubMed Central PMCID: PMC6094980.

36. Kerkar SP, Muranski P, Kaiser A, Boni A, Sanchez-Perez L, Yu $Z$, et al. Tumor-specific CD8+ T cells expressing interleukin-12 eradicate established cancers in lymphodepleted hosts. Cancer research. 2010; 70 (17): 6725-34. DOI: 10.1158/0008-5472. CAN-10-0735. PubMed PMID: 20647327; PubMed Central PMCID: PMC2935308.

37. Pegram HJ, Lee JC, Hayman EG, Imperato GH, Tedder TF, Sadelain $M$, et al. Tumor-targeted $T$ cells modified to secrete IL12 eradicate systemic tumors without need for prior conditioning. Blood. 2012; 119 (18): 4133-41. DOI: 10.1182/ blood-2011-12-400044. PubMed PMID: 22354001; PubMed Central PMCID: PMC3359735.

38. Kerkar SP, Goldszmid RS, Muranski P, Chinnasamy D, Yu Z, Reger RN, et al. IL12 triggers a programmatic change in dysfunctional myeloid-derived cells within mouse tumors. The Journal of clinical investigation. 2011; 121 (12): 4746-57. DOI: 10.1172/JCI58814. PubMed PMID: 22056381; PubMed Central PMCID: PMC3226001.

39. Zhang L, Morgan RA, Beane JD, Zheng Z, Dudley ME, Kassim SH, et al. Tumor-infiltrating lymphocytes genetically engineered with an inducible gene encoding interleukin-12 for the immunotherapy of metastatic melanoma. Clinical cancer research: an official journal of the American Association for Cancer Research. 2015; 21 (10): 2278-88. DOI: 10.1158/1078-0432.CCR-14-2085. PubMed PMID: 25695689; PubMed Central PMCID: PMC4433819.

40. Kunert A, Chmielewski M, Wijers R, Berrevoets C, Abken $\mathrm{H}$, Debets R. Intra-tumoral production of IL18, but not IL12, by TCRengineered $T$ cells is non-toxic and counteracts immune evasion of solid tumors. Oncoimmunology. 2017; 7 (1): e1378842. DOI: 10.1080/2162402X.2017.1378842. PubMed PMID: 29296541; PubMed Central PMCID: PMC5739571.

41. Alsaieedi A, Holler A, Velica P, Bendle G, Stauss HJ. Safety and efficacy of Tet-regulated IL12 expression in cancerspecific T cells. Oncoimmunology. 2019; 8 (3): 1542917. DOI: 10.1080/2162402X.2018.1542917. PubMed PMID: 30723575; PubMed Central PMCID: PMC6350686.

42. Hoyos V, Savoldo B, Quintarelli C, Mahendravada A, Zhang M, Vera J, et al. Engineering CD19-specific T lymphocytes with interleukin-15 and a suicide gene to enhance their anti-lymphomal leukemia effects and safety. Leukemia. 2010; 24 (6): 1160-70. DOI: 10.1038/leu.2010.75. PubMed PMID: 20428207; PubMed Central PMCID: PMC2888148.

43. Krenciute G, Prinzing BL, Yi Z, Wu MF, Liu H, Dotti G, et al. Transgenic Expression of IL15 Improves Antiglioma Activity of IL13Ralpha2-CAR T Cells but Results in Antigen Loss Variants. Cancer immunology research. 2017; 5 (7): 571-81. DOI: 10.1158/2326-6066.CIR-16-0376. PubMed PMID: 28550091; PubMed Central PMCID: PMC5746871.

44. Hu B, Ren J, Luo Y, Keith B, Young RM, Scholler J, et al. Augmentation of Antitumor Immunity by Human and Mouse CAR T Cells Secreting IL18. Cell reports. 2017; 20 (13): 3025-33. DOI: 10.1016/j.celrep.2017.09.002. PubMed PMID: 28954221; PubMed Central PMCID: PMC6002762.

45. Chmielewski M, Abken H. CAR T Cells Releasing IL18 Convert to T-Bet(high) FoxO1(low) Effectors that Exhibit Augmented Activity against Advanced Solid Tumors. Cell reports. 2017; 21 (11): 3205-19. DOI: 10.1016/i.celrep.2017.11.063. PubMed PMID: 29241547. 
1. Palucka AK, Coussens LM. The Basis of Oncoimmunology. Cell. 2016; 164 (6): 1233-47. DOI: 10.1016/i.cell.2016.01.049. PubMed PMID: 26967289; PubMed Central PMCID: PMC4788788.

2. Jena B, Dotti G, Cooper LJ. Redirecting T-cell specificity by introducing a tumor-specific chimeric antigen receptor. Blood. 2010; 116 (7): 1035-44. DOI: 10.1182/blood-2010-01-043737. PubMed PMID: 20439624; PubMed Central PMCID: PMC2938125.

3. Klebanoff CA, Rosenberg SA, Restifo NP. Prospects for geneengineered $T$ cell immunotherapy for solid cancers. Nature medicine. 2016; 22 (1): 26-36. DOI: 10.1038/nm.4015. PubMed PMID: 26735408; PubMed Central PMCID: PMC6295670.

4. Park JH, Geyer MB, Brentjens RJ. CD19-targeted CAR T-cell therapeutics for hematologic malignancies: interpreting clinical outcomes to date. Blood. 2016; 127 (26): 3312-20. DOI 10.1182/blood-2016-02-629063. PubMed PMID: 27207800; PubMed Central PMCID: PMC4929923.

5. Liu B, Yan L, Zhou M. Target selection of CAR T cell therapy in accordance with the TME for solid tumors. American journal of cancer research. 2019; 9 (2): 228-41. PubMed PMID: 30906625; PubMed Central PMCID: PMC6405971.

6. Bonifant $\mathrm{CL}$, Jackson HJ, Brentjens RJ, Curran KJ. Toxicity and management in CAR T-cell therapy. Molecular therapy oncolytics. 2016; (3): 16011. DOI: 10.1038/mto.2016.11. PubMed PMID: 27626062; PubMed Central PMCID: PMC5008265.

7. Tahmasebi S, Elahi R, Esmaeilzadeh A. Solid Tumors Challenges and New Insights of CAR T Cell Engineering. Stem cell reviews and reports. 2019; 15 (5): 619-36. DOI: 10.1007/s12015-01909901-7. PubMed PMID: 31161552.

8. Minutolo NG, Hollander EE, Powell DJ, Jr. The Emergence of Universal Immune Receptor T Cell Therapy for Cancer. Frontiers in oncology. 2019; (9): 176. DOI: 10.3389/fonc.2019.00176. PubMed PMID: 30984613; PubMed Central PMCID: PMC6448045.

9. Stoiber S, Cadilha BL, Benmebarek MR, Lesch S, Endres S, Kobold S. Limitations in the Design of Chimeric Antigen Receptors for Cancer Therapy. Cells. 2019; 8 (5). DOI: 10.3390/cells8050472. PubMed PMID: 31108883; PubMed Central PMCID: PMC6562702.

10. Urbanska K, Lanitis E, Poussin M, Lynn RC, Gavin BP, Kelderman S, et al. A universal strategy for adoptive immunotherapy of cancer through use of a novel T-cell antigen receptor. Cancer research. 2012; 72 (7): 1844-52. DOI: 10.1158/0008-5472.CAN-11-3890. PubMed PMID: 22315351; PubMed Central PMCID: PMC3319867.

11. Lohmueller JJ, Ham JD, Kvorjak M, Finn OJ. mSA2 affinityenhanced biotin-binding CAR T cells for universal tumor targeting. Oncoimmunology. 2017; 7 (1): e1368604. DOI: 10.1080/2162402X.2017.1368604. PubMed PMID: 29296519; PubMed Central PMCID: PMC5739565.

12. Tamada K, Geng D, Sakoda Y, Bansal N, Srivastava R, Li Z, et al. Redirecting gene-modified $T$ cells toward various cancer types using tagged antibodies. Clinical cancer research: an official journal of the American Association for Cancer Research. 2012; 18 (23): 6436-45. DOI: 10.1158/1078-0432.CCR-12-1449. PubMed PMID: 23032741.

13. Koristka S, Cartellieri M, Arndt C, Bippes CC, Feldmann A Michalk I, et al. Retargeting of regulatory $T$ cells to surfaceinducible autoantigen La/SS-B. Journal of autoimmunity. 2013; (42): 105-16. DOI: 10.1016/j.jaut.2013.01.002. PubMed PMID: 23352111.

14. Cartellieri M, Feldmann A, Koristka S, Arndt C, Loff S, Ehninger A et al. Switching CAR T cells on and off: a novel modular platform for retargeting of T cells to AML blasts. Blood cancer journal. 2016; 6 (8): e458. DOI: 10.1038/bcj.2016.61. PubMed PMID: 27518241; PubMed Central PMCID: PMC5022178 directed to CD33, La and the UniCAR platform technology. AE, SL and MC are employed by GEMoaB and CPT, respectively. The other authors declare no conflict of interest.

15. Pishali Bejestani E, Cartellieri M, Bergmann R, Ehninger A, Loff S, Kramer M, et al. Characterization of a switchable chimeric antigen receptor platform in a pre-clinical solid tumor model. Oncoimmunology.
2017; 6 (10): e1342909. DOI: 10.1080/2162402X.2017.1342909. PubMed PMID: 29123951; PubMed Central PMCID: PMC5665068.

16. Feldmann A, Arndt C, Bergmann R, Loff S, Cartellieri M, Bachmann D, et al. Retargeting of T lymphocytes to PSCA- or PSMA positive prostate cancer cells using the novel modular chimeric antigen receptor platform technology "UniCAR". Oncotarget. 2017; 8 (19): 31368-85. DOI: 10.18632/oncotarget.15572. PubMed PMID: 28404896; PubMed Central PMCID: PMC5458214.

17. Rodgers DT, Mazagova M, Hampton EN, Cao Y, Ramadoss NS, Hardy IR, et al. Switch-mediated activation and retargeting of CAR-T cells for B-cell malignancies. Proceedings of the National Academy of Sciences of the United States of America. 2016; 113 (4): E459-68. DOI: 10.1073/pnas.1524155113. PubMed PMID: 26759369; PubMed Central PMCID: PMC4743815.

18. Riddell SR, Sommermeyer D, Berger C, Liu LS, Balakrishnan A, Salter A, et al. Adoptive therapy with chimeric antigen receptormodified $T$ cells of defined subset composition. Cancer journal. 2014; 20 (2): 141-4. DOI: 10.1097/PPO.0000000000000036. PubMed PMID: 24667960; PubMed Central PMCID: PMC4149222.

19. Cao Y, Rodgers DT, Du J, Ahmad I, Hampton EN, Ma JS, et al. Design of Switchable Chimeric Antigen Receptor T Cells Targeting Breast Cancer. Angewandte Chemie. 2016; 55 (26): 7520-4. DOI: 10.1002/anie.201601902. PubMed PMID: 27145250; PubMed Central PMCID: PMC5207029.

20. Cho JH, Collins JJ, Wong WW. Universal Chimeric Antigen Receptors for Multiplexed and Logical Control of $\mathrm{T}$ Cell Responses. Cell. 2018; 173 (6): 1426-38. DOI: 10.1016/j. cell.2018.03.038. PubMed PMID: 29706540; PubMed Central PMCID: PMC5984158.

21. Scarfo I, Maus MV. Current approaches to increase CAR T cell potency in solid tumors: targeting the tumor microenvironment. Journal for immunotherapy of cancer. 2017; (5): 28. DOI: 10.1186/ s40425-017-0230-9. PubMed PMID: 28331617; PubMed Central PMCID: PMC5359946.

22. Sioud M. Releasing the Immune System Brakes Using siRNAs Enhances Cancer Immunotherapy. Cancers. 2019; 11 (2). DOI: 10.3390/cancers11020176. PubMed PMID: 30717461

23. Boutros C, Tarhini A, Routier E, Lambotte O, Ladurie FL, Carbonnel F, et al. Safety profiles of anti-CTLA-4 and anti-PD-1 antibodies alone and in combination. Nature reviews Clinical oncology. 2016; 13 (8): 473-86. DOI: 10.1038/nrclinonc.2016.58. PubMed PMID: 27141885.

24. Hugo W, Zaretsky JM, Sun L, Song C, Moreno BH, Hu-Lieskovan S, et al. Genomic and Transcriptomic Features of Response to AntiPD-1 Therapy in Metastatic Melanoma. Cell. 2016; 165 (1): 3544. DOI: 10.1016/j.cell.2016.02.065. PubMed PMID: 26997480; PubMed Central PMCID: PMC4808437.

25. Simon B, Harrer DC, Schuler-Thurner B, Schaft N, Schuler G Dorrie J, et al. The siRNA-mediated downregulation of PD-1 alone or simultaneously with CTLA-4 shows enhanced in vitro CAR-T-cell functionality for further clinical development towards the potential use in immunotherapy of melanoma. Experimental dermatology. 2018; 27 (7): 769-78. DOI: 10.1111/exd.13678. PubMed PMID: 29704887

26. Martinez M, Moon EK. CAR T Cells for Solid Tumors: New Strategies for Finding, Infiltrating, and Surviving in the Tumor Microenvironment. Frontiers in immunology. 2019; (10): 128. DOI: 10.3389/fimmu.2019.00128. PubMed PMID: 30804938; PubMed Central PMCID: PMC6370640.

27. Vivot A, Jacot J, Zeitoun JD, Ravaud P, Crequit P, Porcher R. Clinical benefit, price and approval characteristics of FDAapproved new drugs for treating advanced solid cancer, 20002015. Annals of oncology: official journal of the European Society for Medical Oncology. 2017; 28 (5): 1111-6. DOI: 10.1093/ annonc/mdx053. PubMed PMID: 28453694

28. Medina PJ, Adams VR. PD-1 Pathway Inhibitors: ImmunoOncology Agents for Restoring Antitumor Immune Responses. Pharmacotherapy. 2016; 36 (3): 317-34. DOI: 10.1002/phar.1714. PubMed PMID: 26822752; PubMed Central PMCID: PMC5071694.

29. Larkin J, Chiarion-Sileni V, Gonzalez R, Grob JJ, Cowey CL, Lao CD, et al. Combined Nivolumab and Ipilimumab or Monotherapy 
in Untreated Melanoma. The New England journal of medicine. 2015; 373 (1): 23-34. DOI: 10.1056/NEJMoa1504030. PubMed PMID: 26027431; PubMed Central PMCID: PMC5698905.

30. Postow MA, Sidlow R, Hellmann MD. Immune-Related Adverse Events Associated with Immune Checkpoint Blockade. The New England journal of medicine. 2018; 378 (2): 158-68. DOl: 10.1056/NEJMra1703481. PubMed PMID: 29320654.

31. Ren J, Liu X, Fang C, Jiang S, June $\mathrm{CH}$, Zhao Y. Multiplex Genome Editing to Generate Universal CAR T Cells Resistant to PD1 Inhibition. Clinical cancer research: an official journal of the American Association for Cancer Research. 2017; 23 (9): 225566. DOI: 10.1158/1078-0432.CCR-16-1300. PubMed PMID: 27815355; PubMed Central PMCID: PMC5413401.

32. Yu Y, Wu H, Tang Z, Zang G. CTLA4 silencing with siRNA promotes deviation of Th1/Th2 in chronic hepatitis B patients. Cellular \& molecular immunology. 2009; 6 (2): 123-7. DOI: 10.1038/cmi.2009.17. PubMed PMID: 19403062; PubMed Central PMCID: PMC4002649.

33. Rupp LJ, Schumann K, Roybal KT, Gate RE, Ye CJ, Lim WA, et al. CRISPR/Cas9-mediated PD-1 disruption enhances antitumor efficacy of human chimeric antigen receptor $\mathrm{T}$ cells. Scientific reports. 2017; 7 (1): 737. DOI: 10.1038/s41598-01700462-8. PubMed PMID: 28389661; PubMed Central PMCID: PMC5428439.

34. Ren J, Zhang $X$, Liu X, Fang $C$, Jiang $S$, June $C H$, et al. A versatile system for rapid multiplex genome-edited CAR T cell generation. Oncotarget. 2017; 8 (10): 17002-11. DOI: 10.18632/ oncotarget.15218. PubMed PMID: 28199983; PubMed Central PMCID: PMC5370017.

35. Knochelmann HM, Smith AS, Dwyer CJ, Wyatt MM, Mehrotra S, Paulos CM. CAR T Cells in Solid Tumors: Blueprints for Building Effective Therapies. Frontiers in immunology. 2018; (9): 1740. DOI: 10.3389/fimmu.2018.01740. PubMed PMID: 30140266; PubMed Central PMCID: PMC6094980.

36. Kerkar SP, Muranski P, Kaiser A, Boni A, Sanchez-Perez L, Yu $Z$, et al. Tumor-specific CD8+ T cells expressing interleukin-12 eradicate established cancers in lymphodepleted hosts. Cancer research. 2010; 70 (17): 6725-34. DOI: 10.1158/0008-5472. CAN-10-0735. PubMed PMID: 20647327; PubMed Central PMCID: PMC2935308.

37. Pegram HJ, Lee JC, Hayman EG, Imperato GH, Tedder TF, Sadelain $M$, et al. Tumor-targeted $T$ cells modified to secrete IL12 eradicate systemic tumors without need for prior conditioning. Blood. 2012; 119 (18): 4133-41. DOI: 10.1182/ blood-2011-12-400044. PubMed PMID: 22354001; PubMed Central PMCID: PMC3359735.
38. Kerkar SP, Goldszmid RS, Muranski P, Chinnasamy D, Yu Z, Reger RN, et al. IL12 triggers a programmatic change in dysfunctional myeloid-derived cells within mouse tumors. The Journal of clinical investigation. 2011; 121 (12): 4746-57. DOl: 10.1172/JCI58814. PubMed PMID: 22056381; PubMed Central PMCID: PMC3226001.

39. Zhang L, Morgan RA, Beane JD, Zheng Z, Dudley ME, Kassim SH, et al. Tumor-infiltrating lymphocytes genetically engineered with an inducible gene encoding interleukin-12 for the immunotherapy of metastatic melanoma. Clinical cancer research: an official journal of the American Association for Cancer Research. 2015; 21 (10): 2278-88. DOI: 10.1158/1078-0432.CCR-14-2085. PubMed PMID: 25695689; PubMed Central PMCID: PMC4433819.

40. Kunert A, Chmielewski M, Wijers R, Berrevoets C, Abken H, Debets R. Intra-tumoral production of IL18, but not IL12, by TCRengineered T cells is non-toxic and counteracts immune evasion of solid tumors. Oncoimmunology. 2017; 7 (1): e1378842. DOI: 10.1080/2162402X.2017.1378842. PubMed PMID: 29296541; PubMed Central PMCID: PMC5739571.

41. Alsaieedi A, Holler A, Velica P, Bendle G, Stauss HJ. Safety and efficacy of Tet-regulated IL12 expression in cancerspecific T cells. Oncoimmunology. 2019; 8 (3): 1542917. DOI: 10.1080/2162402X.2018.1542917. PubMed PMID: 30723575; PubMed Central PMCID: PMC6350686.

42. Hoyos V, Savoldo B, Quintarelli C, Mahendravada A, Zhang M, Vera J, et al. Engineering CD19-specific T lymphocytes with interleukin-15 and a suicide gene to enhance their anti-lymphoma/ leukemia effects and safety. Leukemia. 2010; 24 (6): 1160-70. DOI: 10.1038/leu.2010.75. PubMed PMID: 20428207; PubMed Central PMCID: PMC2888148.

43. Krenciute G, Prinzing BL, Yi Z, Wu MF, Liu H, Dotti G, et al. Transgenic Expression of IL15 Improves Antiglioma Activity of IL13Ralpha2-CAR T Cells but Results in Antigen Loss Variants. Cancer immunology research. 2017; 5 (7): 571-81. DOI: 10.1158/2326-6066.CIR-16-0376. PubMed PMID: 28550091; PubMed Central PMCID: PMC5746871.

44. Hu B, Ren J, Luo Y, Keith B, Young RM, Scholler J, et al. Augmentation of Antitumor Immunity by Human and Mouse CAR T Cells Secreting IL18. Cell reports. 2017; 20 (13): 3025-33. DOI: 10.1016/j.celrep.2017.09.002. PubMed PMID: 28954221; PubMed Central PMCID: PMC6002762.

45. Chmielewski M, Abken H. CAR T Cells Releasing IL18 Convert to T-Bet(high) FoxO1(low) Effectors that Exhibit Augmented Activity against Advanced Solid Tumors. Cell reports. 2017; 21 (11): 3205-19. DOI: 10.1016/j.celrep.2017.11.063. PubMed PMID: 29241547. 